\title{
H.P. Jansen
}

\section{FAITH DEVELOPMENT OF THE TEENAGER DURING THE SUNDAY EVENING WORSHIP SERVICE ${ }^{1}$}

\begin{abstract}
From church conversations with teenagers (born between 1974 and 1994), publications in recent times appeared worldwide and the qualitative investigation in the article is utilized. It seems there are problems in the practice of the faith formation of teenagers in the evening service. The aim of an evening service must always be that God receives all the glory and honour; therefore, the teenager's faith may be enriched. The article chooses for the use of the communicative approach to communicate the gospel to teenagers. The article attempts to use the empirical research method to determine which evening worship needs are experienced by teenagers. The article aims to provide the basis of an adjusted practice theory to propose an improved praxis. The article would provide guidelines for all stakeholders that are involved in the planning and execution of the liturgy of the evening worship service. The purpose of this article is to inspire new thinking and doing. The evening service liturgy should be arranged so that every teenager attending the evening service will be aware of the presence of God.
\end{abstract}

\section{INTRODUCTION}

The following two statements put the actuality of the topic in the centre. Danneels (2001: xiii) wrote:

1 This article is based on the Ph.D. Thesis of the author, titled: Geloofsvorming van die millenniumtiener in die aanddiensliturgie (2007). Bloemfontein. University of the Free State.

Dr H.P. Jansen. E-mail: hjansen58@gmail.com

Acta Theologica

2012 32(2): 86-102

DOl: http://dx.doi.org/10.4314/actat.v32i2.6

ISSN 1015-8758

(C) UVIUFS

<http://www.uovs.ac.za/ActaTheologica> 
The inadequacy of liturgical use of language with respect to modern sensibility, the vocabulary and the idiom of the liturgy do not appeal to modern people.

Redman (2002:81) wrote:

... the main aim is to restore the centrality of Christ, restoring the centrality of the Bible; introducing the Christian year and the lectionary; encouraging richer sacramental practice; and promoting fuller congregational participation in the sermon.

Teenagers are sceptical about the liturgy of the evening worship service (Oosthuizen 2004:3). Every teenager that visits the evening worship service carries his mobile in his pocket. To communicate with them is like learning a foreign language (Du Toit 2004:4). The focus in the worship service moves from the cogitative angle to the affective (emotions) and the conative (experience), according to Babin (1991:28). Babin (1991:63) wrote:

A Christian communicator cannot put forward a message nowadays if he or she does not encourage the affective life of the group.

The processes which take place in society should continuously be addressed in its agenda (Jonker 1968; Pieterse 1991:1; Müller 1996:16; and Heitink 1993). Heitink (1993:287) wrote: "De Kerk en haar leden kunnen wel degelijk een samebindende functie vervullen in de moderne sameleving". Van der Ven (1993:119) wrote: "Faith in God, as hermeneutic-communicative praxis, is the direct object of empirical-theological research, and God in the indirect one. "

Therefore, the words of Pieterse (1992:24) to the congregation are also applicable to the teenager, namely that the church must acknowledge and understand the needs of the teenager. The very needs of the teenager are not accommodated enough by the church. This problem also manifests itself in the liturgy. Robbins wrote: "I'm concerned that too much of our teaching is reduced to what can be communicated by a worship band illuminated by stage lighting and well-placed candles". This article would like to clarify this problem.

It is assumed that liturgical renewal is a legitimate, normal fact. But is it really legitimate and normal? It is assumed that liturgical renewal can make a contribution to the reformation process of the congregation that stands in a live relationship with God. But are congregations willing to transform? These types of questions are asked and answered in the course of this article. The church always remains in the tension of steadiness and variation because the interaction between institution and organism 
demands that the church evaluates herself frequently on the interaction (Laubscher 1987:57).

The question (Willig 2001:120) that is put forward by this article is: "Is God being given the glory and honour when the faith of the teenager is developed in the evening service?"

The research of Barna (2007:1) in the USA reflected that the most common "elements sought by young people were to "worship or make a connection with God'." The research showed that $45 \%$ indicated it as "very important". In South Africa when the research of De la Rey (1992:169) came in the centre, $30 \%$ of teenagers said that the pastor's language used in the liturgy was non-understandable. Jansen (2004:77) wrote that $38 \%$ of the teenagers said the atmosphere of the worship sermon was "relaxed". Relaxed means "soft music, clothes like jeans and tekkies and the warm paint colours of the interior".

The basis of the article is Pneumatological embedded. The Holy Spirit is the declarer and interpreter of the Holy Scripture. God dwells amongst his children through his Word and Spirit. The Holy Scripture was never meant to be an interpreter of liturgical events in a certain time or age.

Practical theology according to Dreyer $(1991: 605)$ is the study of

the communicative acts of faith of people, against the claim of God on the people, as expressed in the Scriptures.

The starting point is the man's actions and communications, and it is found in the human sciences (Janse van Rensburg 2000:93). Pieterse (1992:223) agrees with Van den Berg (1993:20) and defined it as

the communicative events between God and man, and man and man, from the reality of the coming of God through His Word in the World with a view to the eschatological perspective of the coming kingdom of God in the world.

The development in the platinum industry made Rustenburg in 2006 South Africa's quickest growing city. While using qualitative research, the article focused on the largest congregation of the Dutch Reformed Church in Rustenburg as part of the Northern Synod. The congregation of Rustenburg-Bergsig seceded in 1967 from the Dutch Reformed Church congregation of Rustenburg-West. The congregation has a differentiated youth ministry. This means that the primary school children are served in the mornings by a youth worker in their own separate youth sermon and catechism. The teenagers attend the evening worship service. The congregation also differentiates in the evenings in an adult and youth 
worship service. One of the congregation's ministers is responsible for the teenagers' service. Once a month the teenagers attend the service in the church building with the adults.

\section{METHODICAL DESCRIPTIONS}

This article strives to connect praxis to theory. Theology as hermeneutical event demands the same gravity as the praxis. Homiletics is a communicative and hermeneutical act of faith. Homiletics, as part of the practical theology, implies that this communicative act of faith will be discussed in this article (Wagner-Ferreira 2005:54).

Praxis and theory may not be divided and separately discussed in this article. Zerfass (1974:164-177) accentuates the connection between theory and praxis. Praxis means the liturgist is continuously critically reflecting the existing praxis with which he is working. Praxis also means it is aimed at the transformation of the existing church situation. The use of Zerfass's model will enrich the article when the theological theory and existing praxis are granted room to influence each other. Therefore, room will be left for the theological interpretations of the liturgist. The creative interaction between theory and praxis may result in adjusted or even new theories. The result is a liberating and renewing praxis. Praxis means the researcher is constantly trying to reflect the current practice critically while it worked. Praxis also means that it is aimed at transforming the current situation in the church. In the article theory and praxis are juxtaposed. These are two independent entities where there is neither separation nor identification (Pieterse 1993:174). The autonomy of theory and praxis is constantly trying to influence each other.

Praxis and theory are not in opposition to each other in the article. They are two independent entities without division or identification (Pieterse 1993:174). De Wet (2006:59) wrote that the model is a starting point to unease the problems of the current praxis and release new possibilities to enrich the new praxis. Applied to this article, it means that the liturgy of existing evening worship services is praxis 1 . This praxis 1 will be studied critically. The result will then be described in a new praxis, named praxis 2 (De Wet 2006:79). The inter-polar tension takes place between the hermeneutical interaction of the theological theory (Scriptural theory) and the life-situation of the congregation (reality), according to Pieterse (1992:332).

The article chooses for the empiric-critical or event-scientific method (Van Tonder 2001:5). The practical theology as science should be approached empirically (Pieterse 1993:52). The article attempts to 
evaluate the teenagers' experiences and acts of faith scientifically. For the development of a model for the article, we focused on the changes of existing structures in the set liturgy of the Dutch Reformed Church. The response of the teenagers as well as a new model of liturgy will be discussed in more detail in paragraph 6's practical guidelines for planning the evening worship service.

\section{FAITH DEVELOPMENT}

Trimp (1989:25) wrote that the liturgy is for every worshipper, and in the context of the article, the teenager,

weerklank van Gods Woord in hun menseleven. Wanneer de prediking echt de kinderen van God aanspreekt en op hun appelleert, kan deze weerklank onmogelijk uitblijven.

The evening worship's liturgy is part of the pastoral care, youth ministry, children ministry, world mission, diakonia, peer groups, leadership of the congregation (Burger 1999:204). Browning and Reed (1985:2) wrote:

The movement from a split between religious education and liturgy to a growing sense of unity between the educational and liturgical life of the congregation - without destroying the creative tension needed between these two aspects of ministry.

The Search Institute identified six important aspects that can be invested in the faith communion lives of teenagers. They are: a strong affirmation of the role faith traditions play in promoting positive youth development; an asset-based approach to nurture faith development in youth; a planning tool that can help assess and strengthen youth and family programs; practical strategies to energize and involve every member for faith-based asset building; assessment of youth and family programs and lastly strategies to strengthen them (Strommen \& Hardel 2000:113).

Congregations in the Dutch Reformed Church are filled with many different types of families. We develop our faith through classes offered each Sunday morning for children and youth and throughout the year at various times for adults. Faith development occurs when we gather to consider, plan and implement curriculum that reaches people of many perspectives and at every stage of development. Faith is developed as we struggle and celebrate, grow and change. Faith development is living our lives in accordance with our right conscience. 


\section{LITURGY}

The word liturgy is derived from the Greek word "leitourgia". The Greek word is compiled from "leitos" (of the people) and "ergon" (work). The word liturgy includes all the words and acts of the worship service as it is in live interaction with the daily religious life (Barnard 1985:52).

Liturgy focuses on God. Even the sacraments are always interpreted as "primarily ... the action of God" (Farris 1993:72). Preaching the word is always "the preaching of the Word of God" (Farris 1993:70).

Liturgy is filled with experiences with God. Rice wrote that there is perspective for "spiritual experiences that are healthy and in harmony with the broad sweep of Christian tradition" (Rice 1991:37). Teenagers are always in the mood to experience. The faith community must warn teenagers that we need to be careful about efforts to use the outer world's influence to create such experiences for ourselves (Rice 1991:37). Sweet wrote (2000:43) that the "total experience" is the new watchword in postmodern worship. Preachers in the new world do not write there sermons anymore ... "They create total experiences".

Barnard (2000:18) connects experience with reformed liturgy when he wrote: "Wat nu voor het horen geldt, kan van al het zintuigen worden gezegd. Als het geloof 'innerlijk' is, bestaat het in ieder geval in de liturgie niet zonder dat het zich uitdrukt in taal, in beeld, in geur (wierook), in smaak (wijn), dus zonder dat het zich 'verlijfelijkt'”.

Dingemans (1986:58) express that Practical theology is not only notae ecclesiae but also "een gemeente (die) heeft een bedoeling, een organisatievorm, het is een inter-actie van mensen met verwachtingen en opgedane ervaringen". Cilliers (1998:76) wrote that during every worship sermon only one central conclusion must stand out. That must be the truth that the Person of the living God spoke to me.

This article wants to articulate that every Reformed evening worship service can be filled with a rich content, but what is needed is a certain "style" that has been borrowed from the Bible, but it must be everlasting (Cilliers 1998:77).

\section{QUALITATIVE RESEARCH}

Many theologians would define study or research in practical theology primarily as procedural, as they consider this theological department only to be involved in the practical result of one's theology. 
The relationship between theory and praxis can be understood as a bipolar tension (Pieterse 1993:174). Pieterse (1998:181) explains the theory-praxis relationship from a practical theological perspective, and says that it means

the praxis of God happens at means of human actions. But it happens in a partnership between God and man through the work of the Holy Spirit.

Pieterse (1998:181) quotes Heitink (1993):

The deductive approach (starting from the text) and the Inductive approach (starting from the cultural context) are complementary to each other. The structure of practical theology is indeed a bipolar one. Research or the context leads to a new interpretation of the text. This reinterpretation of the text, in turn, sheds new light on the actual situation.

Ricoeur brings an element of interpretation of the text (Pieterse 1993:86). Ricoeur (1981:203) wrote that there is a relationship between the methodology to interpret the text and human acts as an analogue to offset the text. The value of Ricoeur's contribution is that he worked with both the text and human actions. He gave meaning to offset (Pieterse 1993:87).

The methodological model of Ricoeur can be used in the study. The research will seek to capture the spoken communication of the teenagers' need of the evening liturgy worship service in text. With the word "text" the written word is not meant, but the spoken word. The research will evaluate the faith experiences and faith actions of the teenagers concretely and scientifically.

Heitink (1993:195) connects the strategic perspective "who does what" primarily with the "how" and "where". Christianity assumes that a person can change and that society can be renewed from the eschatological perspective of God's kingdom.

For the development of a model for this article there must be changes to existing structures contained in fixed liturgy for evening services of the Dutch Reformed Church. The existing structures and liturgy (in this case the evening worship service) are confirmed and decided by the Dutch Reformed Church's General Synod on the basis of reports from the Commission for Liturgy. Thus it means that this article should continuously recognize the strategic perspective. It cannot be agreed with the view of Heitink $(1993: 151,152)$ when he argues that practical theology moves in the direction of the description and analysis of the problem, evaluating and seeking motives behind the vision and finally made suggestions to improve the current praxis. 
In order to suggest what the faith development of the teenager by means of the evening worships service is, the qualitative method of research is used. According to Leedy (1993:140) the qualitative method is well-suited for the development of comprehension to promote the practice. Two main objects of qualitative research are to describe and analyse the processes by which social reality is built as well as the social relations which bond people (Miller \& Dingwall 1997:3). These social structures, with which qualitative research is involved, are interactively constructed realities and patterns of social relationships.

In this article the content analysis method is used. See Pieterse (ed.) 2001,2005 for a detail description of the content analysis method. The target population is identified (Pieterse 2009:261). A group of 30 respondents were brought together by free will. These included one brother and one sister from a post-modern family, five from a non-biological component, five living in a post-modern setup where the parents were still in their first marriage, eight living with parents of reconstructed post-modern families, and ten who live with a single parent in a post-modern setup. Everybody spoke Afrikaans and belonged to the Dutch Reformed Church congregations in Rustenburg of which their parents were members.

For the purpose of the article, a short summary of the sermon, given by the researcher, is written on the next page. The sermon is divided in two segments containing certain understood units. The segments are also coded. Immink and Verweij (2006) explain coding as the way in which the sermon is read systematically while it is continuously asked what the preacher is doing.

\section{Sermon: Text: Matthew 22:34-40.}

\section{Segment A}

Jesus came to fulfil the Law. His unequivocal answer accentuates everybody's love for God. Take note that love for God consists of an allembracing part of your being that has to answer to the question. No part of man - may it be heart, soul or power - may be withheld to live out the all-overpowering love for God.

In discussions with Jewish listeners Jesus put a new focus to the second part of his answer. You need not like the Jews try to balance between the love for God and the love for your neighbour. "Love thy neighbour like thyself ..." How much do you love yourself? I mean, when 
you look at yourself in the mirror every morning after a rugby match or an evening out with friends?

The new focus that Jesus brought demands that you should first make peace with yourself.

The following codes come to the fore in segment A:

1. Love for God is all-embracing.

2. The love for God must be lived out in my entire life.

3. Love for my neighbour follows self-love.

\section{RESPONDENTS' EXPERIENCE OF THE EVENING SERVICE}

The entire service is basically an interactive chain of events. Barnard and Schuman (2002:27) show that the service is an active hermeneutical process of meaning. This article constantly maintains the viewpoint that the evening service should be approached holistically; not only because the entire evening service should be a Scripture-funded experience for the churchgoer. Long (2001:17) wrote that all people attending the services have an inherent need for authenticity. One of the respondents remarked that the Holy Spirit was present during the praise and worship.

\subsection{Diversity}

The remarks of Boshoff (1985:8), De la Rey (1992) and Jansen (2004) are adjusted to the view of the teenagers. In this article it is shown that different spiritual needs and spiritual styles are experienced in the congregation. Fundamental to the needs of the human being is the inbred need of the community to be part of a group. In the evening service the remark of Long (2001:30) that the congregation hungers for communion with God and other people, was experienced. The author agrees with the observation of Blumer's ed (2005:1):

Churches should provide children with opportunities to receive teaching in words they understand, in 'chunks' that fit their attention spans, and in groups small enough to allow them to interact. These times are not a substitute for the equally vital gathering of whole families for worship and teaching.

York (2000:13) pleads that great care should be given so that the different generative groups in the services should get to know each other 
better. A very important remark from a young respondent was: "The interaction between young people and the adults were positive". Another remarked: "The liturgist should plan the service with the young people early on". Without a doubt this synergism is not only ideal, but, as just shown, also possible.

Diversity is not restricted to communion between people. Diversity is also found in the liturgy. Post-modern man's way of worshipping asks for less structure in the order. Movement and variation are of great importance in the evening service (Stevenson 1981:43).

\subsection{Role-players}

Boshoff (1985:11) and Ouweneel (1978:13) believe that any request for renewal is regarded as young people's rebellion. Liturgists, music directors and administrative support systems should take note of a respondent asking for sound interaction between the teenagers and the different role-players.

\subsection{Liturgy}

As far back as 1992 De la Rey (1992:178) found in an article that young people leave services without getting a message. Teenagers made it clear that long-term relations - formed between the liturgist and the teenagers by frequent interaction on camps, excursions, structured lessons/catechism and services - can assist in bridging the "distance" between the liturgist and the teenagers. The observations by the liturgist are acknowledged by Long (2001:105) when he said that he believes as soon as the liturgist believes God is present in the service, it is shown in his conduct and presentation. In post-modern times the liturgists should still remember that they are destined by God. The liturgist is God's mouthpiece but also an indicator to God's throne. The demands to live up to this responsibility require that the liturgist should always emanate the holy character of worshipping (Long 2001:103). Teenagers seek authenticity from their liturgist. This is even of more importance than the truth.

The liturgy used by the liturgist was filled with audio-visual art forms. Dramas, dances, activities, mimicry and puppetry can enrich and support the liturgy in post-modern times (Jones 2001:21). The liturgist used participation. The reactions of the respondents were: "Having different young people from grade 7 to 11 in one service was nice" Another: "Yes, all enjoyed the participation of the grade groups". From the discussions 
with the teenagers after the service it became clear that they want to be part of the service: "We want to participate in plays, tableaus and dances".

The liturgist used several activities: divide in groups of two, dived chocolate slabs, discussions with each other and discussions with the liturgist. The liturgy is far less word-orientated. Other art forms should be accentuated more. The demand is that teams using these art forms in the liturgy should be clearly informed about the specific contribution to the message they are to present. Another demand is that the art form should be of high standard for it to succeed.

\subsection{Technological explosion}

The remarks of Du Toit (2004:4) and Babin (1991:28) acknowledge the demands on the liturgist and church council to keep pace with the technology. Multi-data presentations are essential today. Photos, DVD clips, PowerPoint slides and the correct font support the liturgy. Effective communication of the Gospel benefits from it. It is noteworthy that the liturgist who worked on this article did not use many audio-visual effects. Unfortunately the reaction of the respondents on this matter was not determined.

Technological accessories are further supported by illustrations. Careful planning and work-teams (symbolic and sermon making groups) can assist in illustrating a certain element of the service. Powerful impactmaking examples or illustrations usually have a surprising moment. This is supported by the remark of a respondent: "The element of neighbourly love, as expressed by the woman looking after the ill in the illustration, made me realize God loves me."

The use of cell phones in the service evoked mixed reaction. One respondent suggested: "Why can't we ask questions by using the cell phones and have them shown on the big screen?" Another remarked: "Some use MXit to write to each other."

\subsection{Music and songs}

All the consulted works (Hutchcraft 1998:3; Borgman 1999:176, Van Tonder 2001:31 and Wagner-Ferreira 2005:62) used in this article clearly showed that the teenager cannot live without music. The use of modern technology such as the iPod results in teenagers having music in their ears all day long. 
During the discussions the respondents often went back to comment on the music and songs. Examples of some of the remarks were positive: "I felt that the music calmed me. The songs' words made us realize that God is present".

Praise and worship are used inter-generatively in the evening service to praise God's holiness and magnitude. The accompanist groups in the congregation constantly exist of a mixture of adults and teenagers. Long (2001:62) believes that justice could only be done to music and singing when as many members of the congregation as possible participate. The suggestion of York (2000:63) to contact the music director early is adhered to by this liturgist. Discussion and planning contributed so that the music and songs fitted into the greater picture of the liturgy.

\section{GUIDELINES FOR A NEW MODEL FOR AN EVENING WORSHIP SERVICE}

Each researcher, as well as every pastor, constantly and critically evaluate the current liturgy of the evening worships service (praxis 1). The article aims to provide some results of an empirical research as well as theoretical reasoning to establish a new practice theory (praxis 2).

The following guidelines can serve as planning instrument two weeks before the evening worship service:

PASTOR: Set already the text and theme from the Scripture reading. Start working on the sermon.

PREACH GROUP: During the weekly meeting with the preaching group the pastor gives background information.

SYMBOLISM: The convener of the symbolism workgroup is informed by the minister about assistance and involvement in the service.

One week before the evening worship service:

MUSIC: Arrange with the leader of the youth music group for the selection of praise and worship songs. Ensure that appropriate songs from the English and Afrikaans repertoire are selected.

VISUAL SUPPORT: Arrange with the leader of the media ministry to set appropriate DVDs aside to be played on the big screen. 
PREACH GROUP: During the weekly meeting discuss the detail exegesis and practical application.

SYMBOLISM: Check with the convener of the symbolism workgroup that their assistance will be used, if needed.

ADMINISTRATIVE SUPPORT: Involve staff from the administration to assist with the copying of the sermon outline and purchases of materials that will be needed.

PASTOR: Prepare the written sermon and PowerPoint presentation.

Afternoon and evening of the worship service:

PASTOR: At least 1.5 hours before the evening worship service connect the laptop and personal electronic systems. Meet the youth band for prayer.

YOUTH LEADERS: Pastor gives information to the youth leaders for their support and involvement in the evening worship service. Pray with them.

MEDIA LEADER: Coordinate with media leader that all relevant DVDs and other electronic support are available.

TEENAGERS: Arrange a few volunteers to share the sermon outline. Organize that they take up the offering.

\section{CONCLUSIONS}

Dingemans's (1991:144) conclusion is also used in the article. It states that an analysis of the praxis done, norms interpreted that comes to us through the tradition and a vision for the future of the practice area. Sweet's opinion (2000: xvii) is essential. He believes there should be one about listening to God's Word and the other in God's World (2000: xvi). He writes:

The greatest symbol for the doubleness of Christian faith is the cross: the intersection of the horizontal and the vertical, the overlap of the divine on the human, the interface of the ancient and the future. A cross Christianity, a faith that is both ancient and future, both historical and contemporary (Sweet 2000: xvi).

The article succeeded in an adjusted praxis theory in praxis 2 by describing praxis 1 and the theory. It became clear in the article that the 
teenager's development of faith can take place in the evening service. Teenagers, who are given the opportunity in the evening service to serve God and each other, will most certainly be part of the future church.

The challenge is for everyone whose path crosses that of the teenagers in the evening service, to grow and to develop the ability in the changing circumstances to manage liturgy of the evening service so that teenagers may be guided to experience God's magnificent deeds.

\section{BIBLIOGRAPHY}

BABIN, P.

1991. The new era in religious communication. Minneapolis: Fortress Press.

BARNA, G.

2007. Barna Update - 10/08/2007 - What Teenagers Look for in a Church.

BaRnaRd, A.C.

1985. Die erediens. Pretoria: NG Kerkboekhandel.

Barnard, M.

2000. Liturgiek als wetenschap van christelijk riten en symbolen. Amsterdam: Vossiuspers.

Blumer, D. Montorius, G. \& Davies, K.

2005. The Interictal Dysphoric Disorder. Epilepsy \& Behavior. 5. 826-840.

Borgman, D.

1999. When Kumbaya is not enough. Massachusetts: Hendrikson Publishers Inc.

Boshoff, C.H.

1985. Beeld van die kerklike jongmens van die tagtigerjare. In Nel, M. (red.) Kerkjeug antwoord (Pretoria: Oosterlig), pp. 1-12.

Browning, R.L. \& ReEd, R.A.

1985. The Sacraments in Religious, Education and Liturgy. Birmingham, Alabama: Religious Education Press

Cilliers, J.

1998. Die uitwysing van God op die kansel. Kaapstad: Lux Verbi.

CLARK, C.

2006. How kids are changing and what it means for youth workers. [Online] Retrieved from: http://www.youthspecialities.com/articles/topics/culture/ changing.php. [2012, 29 September].

DanNeels, G.C.

2001. Opening address, BOEVE, L. \& LEIJSSEN, L. (red.). Sacramental presence in a postmodern context. Leuven: Leuven University Press. 
DE LA ReY, R.P.

1992. Die tienerondersoek van die Nederduitse Gereformeerde Kerk: 'n Gedragswetenskaplike benadering. Pretoria: Universiteit van Pretoria. (Ph.D. Proefskrif).

De Wet, F.J.

2006. Die aanwending van Rolf Zerfass se handelingswetenskaplike model. In die Skriflig 40 (1): 57-87.

Dingemans, G.D.J.

1991. Als hoorder onder de hoorders. Hermeneutiese homelitiek. Kampen: Kok.

DREYER, T.F.J.

1991. Eerste tree in die praktiese teologie - waarheen? Hervormde Teologiese Studies. 47:(3) 605.

Du ToIT, P.A.

2004. Lynnwoodrif se geskenk aan volgende generasie. Kerkbode. 173 (6). p. 4.

FARRIS, S.

1993. Reformed Identity and Reformed Worship, Reformed World 43:69-76.

Heitink, G.

1993. Praktische theologie. Geschiedenis-theorie-handelingsvelden. Kampen: Kok.

HUTCHCRAFT, R.

1998. 12 Sentences that defines a generation. [Online.] Retrieved from: http:// home.pix.za/gc/ge 12/papers/p 101 O.htm. [2006, 8 February.]

ImMink F.G. \& VerweiJ, A.

2006. Dealing with the suffering of Jesus in the Context of a suffering world. An Example of Homiletics. Paper delivered at the Conference of the Societas Homiletica. Pretoria.

Janse van Rensburg, J.

2000. Theology and economics - Pastoral care and poverty. Theological Forum XXVIII $(1,2)$. May.

JANSEN, H.P.

2004. Prediking aan die adolessent in die nuwe millennium. Pretoria: Universiteit van Pretoria. (MA. Verhandeling)

JONES, A.

2001. Alternative worship. Cutting Edge. pp. 19-23.

JONKER, W.D.

1968. Theologie en praktijk. Kampen: Kok.

LAUBSCHER, J.A.

1987. Vastheid en variasie binne die liturgiese ordes van die Nederduitse Gereformeerde Kerk. Pretoria: Universiteit van Pretoria. (DD. Proefskrif). 


\section{LeEDY, P.}

1993. Practical Research. Planning and Design. New York: McMillan Publishing.

LONG, T.G.

2001. Beyond the worship wars. The Alban Institute Inc.

MilleR, G \& Dingwall, R. (eds). 1997. Context and Method in Qualitative Research. London: Sage.

MüLLER, J.C. 1996. Vernuwing in die erediens. In: Smuts, A.J., Vos, C. J. A. \& Nel, M. In gesprek oor die erediens. (Pretoria: NG Kerkboekhandel), pp. 106-120.

OOSTHUIZEN, J.

2004. Kerke moet besef note leer bid. Kerkbode. 173 (6): 3.

OUWENEEL, W.J.

1978. Jeugd in een sterwende eeuw: het lot van jonge mensen in een evolutionistische kultuur. Amsterdam: Buijten \& Schipperheijn.

Pieterse, H.J.C. (Red.), 2001. Desmond Tutu's message. A Qualitative Analysis. Leiden-Boston-Koln.

Pieterse, H.J.C.

1991. Gemeente en prediking. Pretoria: NG Kerkboekhandel

1992. 'n Prakties-Teologiese kommunikasieteorie vir die prediking. Praktiese Teologie in Suid-Afrika 7(1).

1993. Praktiese teologie as kommunikatiewe handelingsteorie. Pretoria: RGN-Uitgewers.

1998. A Theological Theory of Communicative Actions, Religion and Theology. 2 (1): 176 - 194.

2005. Die rol van Godskennis in die ontmoetingsgebeure met God in die prediking, In die Skriflig. 39 (3):409-422.

2009. Prediking wat God ter sprake bring in die Suid-Afrikaanse konteks van regstellende aksie. In: Immink, F.G. \& Vos, C.J.A. God in 'n kantelende wêreld. (Pretoria: Protea Boekhuis), pp. 250-273.

RICE, $\mathrm{H}$.

1991. Reformed Spirituality. An introduction for believers. Louisville: John Knox Press.

Ricoeur, P.

1981. Hermeneutics and the Human Sciences. Cambridge: Cambridge University Press.

SteVenson, K.

1981. Family Services. London: SPCK. 
Strommen, M.P. \& Hardel, R.A. (editors)

2000. Passing on the faith: A radical new model for youth and family ministry. Winona: Saint Mary's Press.

SWEet, L.I.

2000. Postmodern pilgrims. First Century Passion for the $21^{\text {st }}$ Century World. Nashville: Broadman \& Holman.

Van Der Ven, J.A.

1993. Practical theology: An empirical approach. Kampen: Kok

VAN TONDER, B.J. 2001. Kerkmusiek vir hedendaagse tieners. Pretoria: Universiteit van SuidAfrika. (M.Diac. Verhandeling).

WAGNeR-FERREIRA, E.C.

2005. ' $n$ Empiriese navorsing rakende die bedieningsbehoeftes van die tieners in die NG Gemeente Waverley met spesifieke verwysing na die erediens. Pretoria: Universiteit van Pretoria. (M.A. Verhandeling).

WALCOTT, H.F.

1994. Transforming qualitative data. Thousand Oaks: Sage Publications.

WILLIG, C.

2001. Introducing qualitative research in psychology. Philidelpia: Open University Press.

YORK, T.W.

2000. Cross-generational worship. Journal of family worship 14(1):10-19.

ZERFASS, $R$.

1974. Praktische Theologie als Handlungswissenschaft. In: Klostermann, F. \& Zerfass, R. (Hrsg.) Praktische Teologie heute. (München/Mainz: Kaiser/ Grunewald). pp. 164-177.

Keywords

Faith development

Millennium teenager

Improved praxis
Trefwoorde

Geloofsvorming

Tiener

Verbeterde praksis 